BJHS: Themes 4: 1-27, 2019. C British Society for the History of Science 2019. This is an Open Access article, distributed under the terms of the Creative Commons Attribution licence (http:// creativecommons.org/licenses/by/4.0/), which permits unrestricted re-use, distribution, and reproduction in any medium, provided the original work is properly cited.

doi: $10.1017 / b j t .2019 .8$

\title{
How collections end: objects, meaning and loss in laboratories and museums
}

\author{
BORIS JARDINE*, EMMA KOWAL"* AND \\ JENNY BANGHAM"
}

\begin{abstract}
Collections are made and maintained for pleasure, for status, for nation or empire building, for cultural capital, as a substrate for knowledge production and for everything in between. In asking how collections end, we shift the focus from acquisition and growth to erosion, loss and decay, and expose the intellectual, material and curatorial labour required to maintain collections. In this introductory essay, we draw together insights from the history of science and from science and technology studies to investigate the dispersal, destruction, absorption, repurposing and repatriation of the diverse scientific collections discussed in the papers that make up this issue of BJHS Themes, and many other collections besides. We develop a distinction first suggested by the curator and bibliographer John Willis Clark between 'working' collections of objects valued for the information they hold or produce, and 'unique' collections of objects valued for their historical singularity. We show that in many cases, the 'end' of an object or collection involves a shift in the dominant account of its cultural value from 'working' to 'unique' or vice versa. Moving between the laboratory, the museum and difficult-to-classify spaces in between, we argue that 'ending' is not anathema to 'collecting' but is always present as a threat, or as an everyday reality, or even as a necessary part of a collection's continued existence. A focus on ending draws attention not only to the complex internal dynamics and social contexts of collections, but also to their roles in producing scientific knowledge.
\end{abstract}

Collecting is a fundamental human activity. The Latin colligere - 'to gather together' draws on the Proto-Indo-European 'leg', a root that has spawned terms that mean 'to gather' (to catalogue) but also 'to speak', in the sense of 'gathering words' (lecture,

Department of History and Philosophy of Science, University of Cambridge, Free School Lane, CB2 3RH, United Kingdom. Email: bj210@cam.ac.uk.

"Alfred Deakin Institute for Citizenship and Globalisation, School of Humanities and Social Sciences, Deakin University, Melbourne, Australia. Email: emma.kowal@deakin.edu.au.

"*** Department of History and Philosophy of Science, University of Cambridge, Free School Lane, CB2 3RH, United Kingdom. Email: jb252@cam.ac.uk.

We are extremely grateful to all of the participants in the How Collections End workshop, and in particular to Simon Schaffer, Simon Werrett, Nick Hopwood, Nick Jardine and two anonymous reviewers for reading and commenting on drafts. Boris Jardine is supported by the Leverhulme Foundation and Newton Trust (RG79693/RG81914), Emma Kowal's research is supported by an Australian Research Council Future Fellowship (FT160100093) and Jenny Bangham is supported by the Wellcome Trust (grant number 200299/Z/15/Z). We dedicate this essay to Avery Rosalind Jardine Bangham. 
lexicon, dialect, election). ${ }^{1}$ To communicate is to collect. From early childhood, we curate the flow of objects through our lives, saving items we value and discarding any surplus. From childhood rock collections to social-media profiles, we hone our skills of discrimination, expression, pleasure and self-fashioning. Grander collections hold sway in the academic and popular imagination: national museums and libraries, the great public and private collections of artworks, archives of governance, and, increasingly, the data harvested by states and tech companies alike. Nations and empires have their own logics of acquisition: collections of data, cultural artefacts or tissues can be as important as territory in establishing authority over a population. In the sciences, collections - of instruments, specimens, samples and objects - have played a defining role in disciplinary identity, pedagogy, experimental practice and public engagement. But in the excitement of creation and expansion, it is easy to overlook the constant work required to stave off erosion, failure and loss.

In fact, collecting and ending often travel together. Since the nineteenth century, the perception that certain things - environments, cultures, animals - are about to end has prompted mass collections of specimens, stories and artefacts before it is 'too late'. ${ }^{2}$ Institutional collections are usually intended as an end point for the objects that fall into their care: further circulation is tightly controlled. Near-obsolete objects that might have been in danger of abandonment find a safe end as 'collectables' that illustrate some time, place or way of life worth remembering. The less likely an object is to survive, the greater its value to a collection. Yet little attention has been paid to how collections themselves end. Historians have traced modern collections back through the positive achievements of past collectors and curators, and in these stories, the inherent value of a collection is often taken for granted. Our focus on endings points to an alternative history: of accidental collections and collections that have been diminished, misplaced, dispersed or destroyed. The lens of ending also makes visible the perpetual care, assessment, de-accessioning and editing needed for collections to persist.

This edition of BJHS Themes collects nine articles, one photo-essay and two commentaries on endings, collections and science. The papers were first shared at a workshop in the Whipple Museum of the History of Science in Cambridge, UK, and some of the reference points and case studies for our discussion in this introductory essay relate to the exceptionally rich collections (of scientific instruments, books, skulls, blood, statues) in the orbit of Cambridge (see in particular Jardine, this issue). The essays presented here also gather stories from Europe, the United States and the Asia-Pacific region on collections of seeds (Curry), microscope slides (Hopwood), blood (Roque), human remains (Kakaliouras), flies (Bangham), DNA samples (Skinner and Wienroth) and things that were never intended for collection, including museum props (Kowal), impromptu collages (Gómez López) and even museum catalogues themselves (Porter). Taking these essays together, we find that when collections end, so do careers, communities,

1 Walter Skeat, The Concise Dictionary of English Etymology, Ware: Wordsworth Editions, 1993.

2 Fernando Vidal and Nélia Dias (eds.), Endangerment, Biodiversity and Culture, London and New York: Routledge, 2016; Joanna Radin, Life on Ice: The History of New Uses for Cold Blood, Chicago and London: The University of Chicago Press, 2017; Carrie Friese, Cloning Wild Life: Zoos, Captivity, and the Future of Endangered Animals, New York: New York University Press, 2013. 


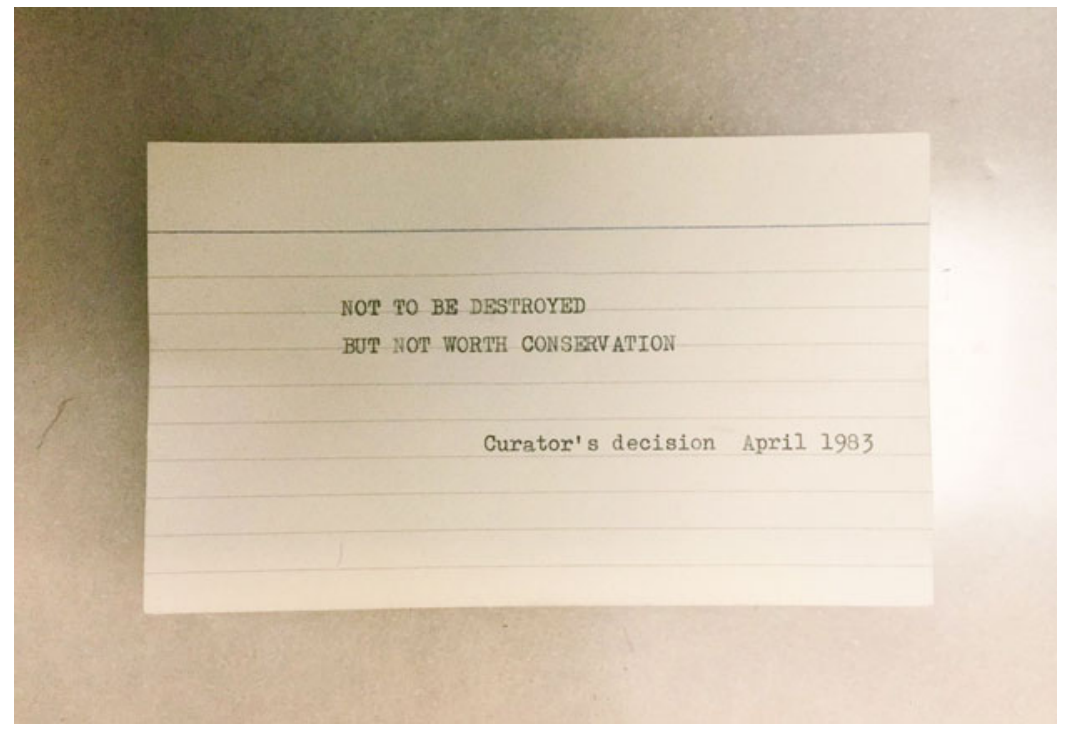

Figure 1. Note accompanying an object (woven mat) in the Pitt Rivers Museum, Oxford. Image tweeted by @Pitt_Stores, twitter.com/Pitt_Stores/status/869882819190951936, accessed 25 April 2019. Copyright, Pitt Rivers Museum, Oxford University.

disciplines and empires, and these broader stories have enduring social, political and intellectual consequences.

How do collections end? In a general sense, collections are sites of intense competition between forces of dissipation and of preservation (Figure 1). These forces are physical, as seen most clearly in collections of working or fragile objects that must be carefully maintained lest they disintegrate or decay. ${ }^{3}$ Forces can also be legal and moral, as in collections of human remains and personal possessions that are subject to competing claims of ownership or control. This depends on social and cultural setting: collections can endure only when they are supported by relevant expertise, communal desire and social order. ${ }^{4}$ In addition to the maintenance work needed to preserve objects, labour is needed to preserve the organizing logic, meaning and accessibility of collections in the face of institutional or disciplinary shifts. In each of these ways - technological, social, institutional and disciplinary - failure is a constant possibility and maintenance must be an active process, requiring intellectual, social, cultural and political labour and negotiation. An apparent paradox that we explore in what follows is that maintenance at all of these different levels can require ending as a matter of routine: the deletion

3 For a positive view of decay in heritage see Caitlin DeSilvey, 'Observed decay: telling stories with mutable things', Journal of Material Culture (2006) 11, pp. 318-338.

4 On the necessity of skills and techniques for the functioning of technologies see Daniel Headrick, Power over Peoples: Technology, Environments, and Western Imperialism, 1400 to the Present, Princeton, NJ: Princeton University Press, 2009. 
of data in the interest of privacy, the destruction of specimens in the interest of conservation, the death of organisms in the interest of their utility.

In this way, we understand 'collections' primarily as sites of relationships and meanings that are created and maintained around objects. These relationships and meanings involve disciplinary conventions, political circumstances, regulatory structures, classificatory systems and networks of affect and care. In light of this socially oriented understanding of what collections are, the term 'ending' is broad and productively ambiguous, and can refer to changes to a collection's identity, perceived value, geographic location and meaning. To pay attention to ending is to pay attention to the shifting fortunes of things, to the labour of their maintenance, and to the reality of dispersal as a negative and positive force. The essays in this issue show that whether in a 'centre of calculation' like Cambridge, or a seed bank on a farm in Missouri, or an Australian state museum, a collection or group of collections is not a static entity: the twin forces of circulation and maintenance have a far greater bearing on the nature of collections than the more familiar conditions of stasis and permanence. ${ }^{5}$ Objects have been packed up, moved around, unpacked, repacked, stored, display, loaned out, returned, catalogued, recatalogued, lost, found, photographed, scanned, described, published, replaced, faked, stolen; they have decayed, been conserved and decayed again. ${ }^{6}$ Such processes might alter (even end) the identities of collections, their ownership or their meanings. Conversely, 'ending' is not anathema to 'collecting': in some cases, managing the endings of objects is necessary to the maintenance of a collection.

Scientific collections constitute a distinctive 'layer' in the history of scientific practice and knowledge making..$^{7}$ Assemblages of specimens, teaching objects, instruments and data play a dynamic role in relation to theory, pedagogy, experimentation and the various technologies of representation, all of which they both determine and are determined by. This semi-autonomy means that the endings of scientific collections are particularly complex. If a collection of data is lost, a vital source of authority vanishes with it. When specimens degrade or institutions deem them too costly to preserve, careers, museums and even disciplines are under threat. Nor are these changes necessarily tied to commonly held perceptions of scientific relevance or meaning: collections can die before their time, but they can also outlive their usefulness (only to become useful

5 Lorraine Daston, 'The sciences of the archive', Osiris (2012) 27, pp. 156-187; Tony Bennett, The Birth of the Museum: History, Theory, Politics, London and New York: Routledge, 1995; Bennett, Museums, Power, Knowledge: Selected Essays, London and New York: Routledge, 2018; Sharon Macdonald, 'Introduction', in Sharon Macdonald and Gordon Fyfe (eds.), Theorizing Museums: Representing Identity and Diversity in a Changing World, Oxford: Blackwell Publishers, 1996, pp. 1-18; Chris Gosden and Frances Larson, Knowing Things: Exploring the Collections at the Pitt Rivers Museum 1884-1945, Oxford: Oxford University Press, 2007.

6 Research into the 'dynamics' of museums is currently being conducted by, amongst others, the Royal Holloway/Kew Gardens project The Mobile Museum: Economic Botany in Circulation. See their working papers and related publications, available at intranet.royalholloway.ac.uk/geography/research/mobilemuseum/outputs.aspx, accessed 14 December 2018.

7 For a periodization of this idea see John V. Pickstone, 'Museological science? The place of the analytical/ comparative in nineteenth-century science, technology and medicine', History of Science (1994) 32, pp. 111138. Peter Galison refers to 'layers' of theoretical and observational scientific practices in 'History, philosophy, and the central metaphor', Science in Context (1988) 2, pp. 197-212, esp. $207 \mathrm{ff}$. 
again under a new paradigm). In other words, collections are at times out of step with other aspects of scientific practice. These contradictions and dislocations have an obvious resonance with Thomas Kuhn's 1962 The Structure of Scientific Revolutions - a book very much concerned with collections (of data) and endings (of paradigms). ${ }^{8}$ We return to Kuhn in our conclusion.

A more recent but similarly canonical treatment of endings in the history of science is Peter Galison's How Experiments End. ${ }^{9}$ Here the focus is less on failure than on finality: experiments end when consensus is reached, though of course the route to consensus, its stability and its precise nature are far from straightforward. This is the other meaning of 'ending' that we wish to apply to scientific collections: the end of a collection is its agreed purpose. In this sense, collections require material, social, institutional and intellectual maintenance in order to endure, and failure in any one of these areas can lead to dispersal, destruction or neglect. ${ }^{10}$ One crucial insight of Galison's work is that experiments end when just enough local, material, institutional and social specificity is removed from the various sites in which they have been carried out. The end of an experiment is its transformation into accepted data, agreed results, the printed (and now, increasingly, digital) surrogate of a mechanical process. This has a particular resonance for what we will term 'working' collections, where intellectual purpose takes priority over preservation and the singularity of the objects themselves. Collections, like experiments, are made to move through representations, statistics, descriptions and other surrogates. Happy consensus about the meaning of a collection may break down, however, when objects are themselves prized over any given use to which they may be put. What, for instance, is the purpose or meaning of an image or copy of a 'unique' object? This question, and the host of others it leads to, have ramifications for the fates of collections, in terms of both failure and success, loss and preservation. ${ }^{11}$

Endings are everywhere. In this introduction, and in the papers that follow, we leave our definition of ending open. Drawing on scholarship from the history of science, science and technology studies, museum studies and beyond, we examine what various kinds of endings - from disciplinary change, to destruction, to repatriation and recycling - can tell us specifically about scientific collections, their meanings and their power.

Scholarship on the end of scientific collections, from both history of science and science and technology studies more broadly, can make a timely contribution to academic and public discussions for at least three reasons. First, museums around the world are in crisis. Many are confronting funding cuts and can no longer afford basic

8 Thomas S. Kuhn, The Structure of Scientific Revolutions, Chicago and London: The University of Chicago Press, 2012 (first edn 1962).

9 Peter Galison, How Experiments End, Chicago and London: The University of Chicago Press, 1987.

10 For a detailed account of the reasons for the long-term persistence of scientific collections see Daston, op. cit. (5).

11 Bruno Latour, Pandora's Hope: Essays on the Reality of Science Studies, Cambridge, MA: Harvard University Press, 1999 , pp. 24-79. A similar approach is taken to the history of scientific collections in Lorraine Daston (ed.), Science in the Archives: Pasts, Presents, Futures, Chicago and London: The University of Chicago Press, 2017, esp. 'Introduction', and Chapter 2 (David Sepkoski, 'The earth as archive: contingency, narrative, and the history of life', pp. 53-83). 
maintenance of their objects. This reduction in state investment reflects a wider, manysided issue: the once unquestioned assumption that the museum is a universal good no longer holds. On the one hand, the rise of neo-liberalism, with shrinking government services and the perception of pervasive and ever-increasing security threats, has diverted resources away from the museum sector in many countries. From a very different direction, 'source' communities, be they national governments or indigenous groups, are shifting the focus from the objects held in a collection to their provenance. ${ }^{12}$ This has coincided with demands for the return of many objects by representatives of the states or indigenous groups from whom they were bought, stolen, bartered or otherwise acquired. These reversals (of funding, and the ownership of objects) prompt critical attention to how collections end.

A second line of interest in how collections end concerns collections of things that defy easy understanding as 'objects' at all. ${ }^{13}$ The most significant collections amassing in the twenty-first century are digital and are owned by corporations rather than public institutions. We are sharing more information about ourselves than ever before with little idea of who can lawfully - or unlawfully - access the data and for what purposes. As the recent Facebook scandals have illustrated (see Reardon, this issue), public trust in corporate data holders is shrinking as fast as digital collections are accumulating. ${ }^{14}$ The 'Right to Be Forgotten' movement is one example of attempts by citizens to erase their endlessly replicated digital footprints. ${ }^{15}$ As many papers highlight (see in particular Skinner and Wienroth, this issue), the problem of incomplete deletion of digital traces is informed by historical understandings of copies and reproductions (see Kowal, this issue).

Finally, interest in the end of collections reflects widespread anticipation of the end of the biggest 'collection' of all: the biota of the planet. In what has been termed the 'Anthropocene' - the proposed geological epoch that recognizes humans as the greatest influence on the Earth's ecologies - academic and popular interest in endings is high, and formerly obscure historical collections are deemed to have an importance that would have been inconceivable only a few decades ago. ${ }^{16}$ Environmental destruction, pollution, biodiversity depletion and climate change are ending species and even entire ecologies. Collections such as the Svalbard seed vault and the UK-based Frozen Ark Project are

12 Following current Australian convention, in this essay we capitalise 'Indigenous' when referring to the Indigenous people of Australia and use the lower case 'indigenous' when referring to indigenous peoples globally.

13 Bronwyn Parry and Beth Greenhough, Bioinformation, Cambridge: Polity Press, 2018; Yuk Hui, On the Existence of Digital Objects, Minneapolis: University of Minnesota Press, 2016.

14 See Shoshana Zuboff, The Age of Surveillance Capitalism: The Fight for a Human Future at the New Frontier of Power, London: Profile Books, 2019.

15 Alessandro Mantelero, 'The EU proposal for a General Data Protection Regulation and the roots of the “right to be forgotten”, Computer Law \& Security Review (2013) 29, pp. 229-235.

16 See the articles collected in the Philosophical Transactions of the Royal Society B special issue Biological Collections for Understanding Biodiversity in the Anthropocene (ed. Emily K. Meineke, Barnabas H. Daru, T. Jonathan Davies and Charles C. Davis) (2019) 374; also Nicole Heller, 'Natural history museums have never been more necessary', Apollo Magazine, 13 December 2018, available at apollo-magazine.com/ natural-history-museums-have-never-been-more-necessary, accessed 14 December 2018. 
gaining attention as forms of insurance against the future. They offer a way to maintain collections of plants and animals beyond extinction, if only in a frozen form with no guarantee of reanimation. ${ }^{17}$ In the face of so many endings, it is not surprising that interest in maintenance is also growing. ${ }^{18}$ Several papers in this issue (especially Curry, Bangham) reflect on such collections and the work done to maintain them, and offer insights into how to recognize and accept when the end has come (see also Skinner and Wienroth, Roque).

\section{Ways of ending}

'Ending' has many useful valences beyond destruction or dispersal. As touched on in our discussion of Galison above, another meaning of 'end' is 'completion'. Applied to collections, this could translate as the shifting and never quite articulated sense that if a collection has a guiding logic then it might also have a conclusion - a point at which further objects should not be added, or preservation efforts should cease. But this, as we will see, is a very long way from current museum policies, which are generally committed to the idea of perpetual acquisition and preservation. Typically, then, this kind of end point applies only to those smaller, private collections that might arrive at a museum when a collector dies and the collection becomes eponymous. Named natural-history collections are often absorbed into larger public and research collections and the identity and integrity of those sub-collections can be lost if assimilation is too complete. ${ }^{19}$ While this can be a side effect of 'good' curatorial practice, it can also be a deliberate political act. An example of the latter is seen in Kowal's paper, where some Indigenous curators cultivate a conscious disinterest in collectors in order to reinstate Indigenous understandings of objects and their value. Almost all museum collections contain named or silent sub-collections, each with a different history, internal coherence and even agency within the overarching collection.

Related to this is another kind of ending - more prosaic, but perhaps more profound. Collections change purpose, or their purpose shifts: they end up. A personal collection is altered when it enters an institution (Porter, this issue); ${ }^{20}$ a local or amateur collection might be incorporated into a national and professional one (Curry, this issue). Charles Darwin's specimens from the Beagle voyage present an unusually well-documented

17 Joanna Radin and Emma Kowal, 'The politics of low temperature', in Joanna Radin and Emma Kowal (eds.), Cryopolitics: Frozen Life in a Melting World, Cambridge, MA: MIT Press, 2017, pp. 3-15.

18 On a recent scholarly turn to maintenance, caretaking and repair and their significance for innovation, power and knowledge see, for example, Andrew L. Russell and Lee Vinsel, 'After innovation, turn to maintenance', Technology and Culture (2018) 59, pp. 1-25; Steven J. Jackson, 'Rethinking repair', in Tarleton Gillespie, Pablo J. Boczkowski and Kirsten A. Foot (eds.), Media Technologies: Essays on Communication, Materiality, and Society, Cambridge MA: MIT Press, 2014, pp. 221-240.

19 Samuel J.M.M. Alberti, 'Placing nature: natural history collections and their owners in nineteenthcentury provincial England', BJHS (2002) 35, pp. 291-311.

20 See also Caitlin Doherty, 'Home storage: the treatments of domestic collections of aeronautica by the Science Museum and the National Air and Space Museum', in Mirjam Brusius and Kavita Singh (eds.), Museum Storage and Meaning: Tales from the Crypt, London and New York: Routledge, 2018, pp. 140-151. 
instance of this: they were widely dispersed after Darwin sent them back to his Cambridge colleague John Stevens Henslow. Darwin's subsequent fame prompted the reidentification of his specimens in numerous museums. ${ }^{21}$ Conversely, an institutional collection may itself enter the historical doldrums, surviving without purpose (Roque, Hopwood, this issue). Collections might also be suspended, as in the collections of artworks bought as investments that end up in visitorless storerooms called 'freeports'. ${ }^{22}$ With limited funding but reluctance to de-accession objects, vast collections inhabit the stores of many European museums, often without the resources for maintenance, documentation or repair. ${ }^{23}$

Then again, a collection might be repurposed as a source of useful objects for science or cultural identity. While the rise and fall of disciplines over time might threaten a collecting paradigm, they may also reveal new possibilities. Old collections of blood samples, for example, have piqued the interest of evolutionary microbiologists who mine them for plasmodium parasites that pre-date the era of drug resistance. ${ }^{24}$ Collections may themselves be collected if they are retained to illustrate the logic and context of their formation. Many anthropological museums, for example, are remaking themselves as reflexive commentators on their own history. In this vein, Samuel Redman asks whether the Museum für Völkerkunde in Hamburg - now the Museum am Rothenbaum: Kulturen und Künste der Welt - should be converted from an anthropology museum to a history museum, testifying to an earlier mode of collection. ${ }^{25}$

Collections do not always end through processes of neglect or passive absorption: ending may, of course, be violent and final. Natural hazards have destroyed many collections, from the Great Kantō earthquake that razed Tokyo's libraries in 1923 to the destruction of the Lyttleton museum in the Christchurch earthquakes of 2010 and 2011. ${ }^{26}$ The catastrophic fire that destroyed Brazil's Museo Nacional on 3 September 2018 is the worst museum disaster in at least a century, and reminds us that 'natural'

21 See Duncan M. Porter, 'The Beagle collector and his collections', in David Kohn (ed.), The Darwinian Heritage, Princeton, NJ: Princeton University Press, 1985, pp. 973-1019. Many of Darwin’s specimens remained in Cambridge, though even there they were dispersed amongst the university's different museums; see Alison M. Pearn, A Voyage round the World: Charles Darwin and the Beagle Collections in the University of Cambridge, Cambridge: Cambridge University Press, 2009.

22 Graham Bowley and Doreen Carvajal, 'One of the world's greatest art collections hides behind this fence', New York Times, 28 May 2016, at nytimes.com/2016/05/29/arts/design/one-of-the-worlds-greatestart-collections-hides-behind-this-fence.html, accessed 17 April 2019; Hito Steyerl, 'Duty-free art', e-Flux, March 2015, at e-flux.com/journal/63/60894/duty-free-art, accessed 17 April 2019.

23 Placing an object in store is, of course, a double-edged process: storerooms themselves are by no means homogeneous spaces, and nor are all objects in store by any means 'lost' or even neglected. See Brusius and Singh, op. cit. (20).

24 Radin and Kowal, op. cit. (17).

25 Samuel J. Redman, 'Have anthropology museums become history museums? A visit to Museum für Völkerkunde in Hamburg, Germany', History of Anthropology Newsletter (2016) 23, at histanthro.org/ notes/museum-fur-volkerkunde, accessed 17 April 2019.

26 It has been functioning as a virtual museum since then, although plans for a new building are under way; see lytteltonmuseum.co.nz/\#about, accessed 17 April 2019. Wikipedia maintains a 'List of destroyed libraries' page that has many more examples: en.wikipedia.org/wiki/List_of_destroyed_libraries, accessed 17 April 2019. 
disasters are often deeply political. ${ }^{27}$ The calamity in Rio is widely attributed to woefully inadequate state resources to maintain the building and collections, and brings home clearly that disasters are often contingent on the presence or absence of planning and maintenance. A Google review of the museum posted just weeks before the fire now seems prophetic: 'Impressive work is done here - with such little money'. ${ }^{28}$

Human action threatens collections in other ways. Climate change is accelerating threats to collections that face unprecedented hazards. ${ }^{29}$ Ominously, the entrance to the Svalbard Seed Bank in Norway, designed to safeguard a million seed varieties against any human-induced or natural disaster, was flooded in the summer of 2017, the hottest on record. ${ }^{30}$ Deliberate human efforts to destroy collections are often associated with political conflict (Figure 2). Monuments are vandalized, and graves and memorials are desecrated. The deliberate destruction of heritage in Iraq and Syria has become a prominent feature of twenty-first-century warfare. Virtual collections are particularly vulnerable to dissipation, as demonstrated by recent efforts in the United States to 'guerrilla archive' climate data after the election of Donald Trump in anticipation of mass deletion. ${ }^{31}$ The threat of losing data en masse has ironically increased public interest in more mundane (but no less worrying) shifts of terminology on US government websites. ${ }^{32}$ Other more dramatic events also illustrate possible protective effects of ending. Only after the Taliban destroyed the Bamiyan Buddhas in Afghanistan was the site added to UNESCO's List of World Heritage in Danger, which collates sites

27 At the time of writing the most useful commentaries on the fire are the Twitter thread by Gabi Sobral (@darkgabi), at twitter.com/darkgabi/status/1036715635160563714; James Gorman's piece in the New York Times, 4 September 2018, at nytimes.com/2018/09/04/science/brazil-museum-fire.html; Alejandro Chacoff's in the New Yorker, 16 September 2018, at newyorker.com/news/dispatch/brazil-lost-more-thanthe-past-in-the-national-museum-fire; and Ed Yong's in The Atlantic, 4 September 2018, at theatlantic.com/ science/archive/2018/09/brazil-rio-de-janeiro-museum-fire/569299; Ana Lucia Araujo's at the website HistoryExtra: historyextra.com/period/modern/brazil-national-museum-fire-context-explained (all accessed 22 November 2018). Ricardo Ventura Santos - a contributor to the How Collections End workshop and affiliate of the Brazilian National Museum - has also addressed the fire in relation to the present topic in his " "Hello + invitation: 'How Collections End"”: the fire at the Brazilian National Museum and shared stories', Cadernos de Saúde Pública (Reports in Public Health) (2018) 34, pp. 1-3. Historical background on the relationship between the National Museum and different political regimes is given in Regina Horta Duarte, Activist Biology: The National Museum, Politics, and Nation Building in Brazil, Tucson: University of Arizona Press, 2016.

28 Comment from Cibele Bustamente, Google Search review of Museo Nacional.

29 Roos 2015: futureofmuseums.blogspot.com.au/2015/12/keeping-history-above-water.html, accessed 17 April 2019. The Keeping History above Water project, founded in Newport, Rhode Island, focuses on the effects of climate change on heritage sites and museums. See historyabovewater.org/about, accessed 17 April 2019.

30 Damian Carrington, 'Arctic stronghold of world's seeds flooded after permafrost melts', The Guardian, 19 May 2017, at theguardian.com/environment/2017/may/19/arctic-stronghold-of-worlds-seeds-floodedafter-permafrost-melts, accessed 17 April 2019.

31 Jerome Whitingdon, 'Environmental data, guerrilla archiving, and the Trump transition', Dispatches Cultural Anthropology, 17 January 2017, at culanth.org/fieldsights/1048-environmental-data-guerrillaarchiving-and-the-trump-transition, accessed 17 April 2019.

32 See Julia Belluz and Umair Irfan, 'The disturbing new language of science under Trump, explained', Vox, 30 January 2018, vox.com/2017/12/20/16793010/cdc-word-ban-trump-censorship-language, accessed 25 April 2019. 


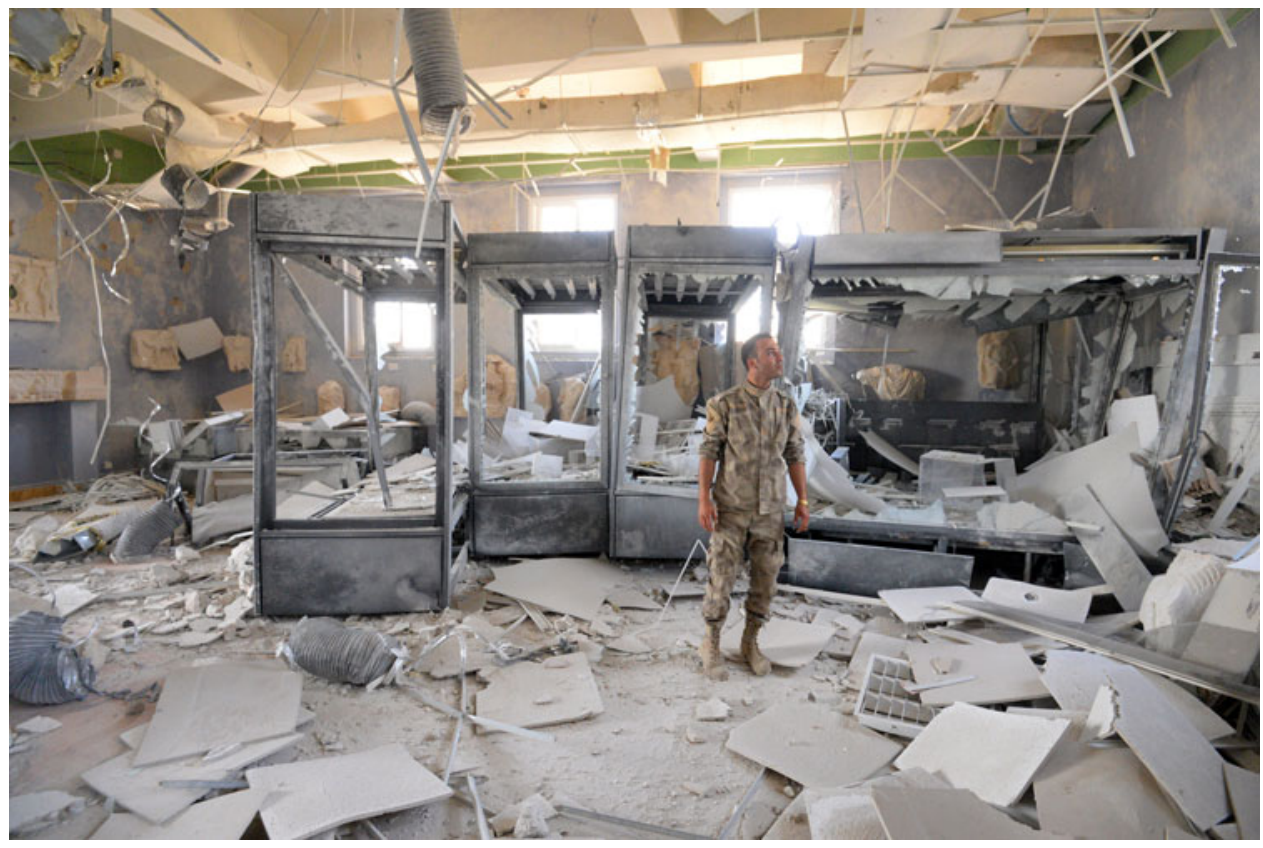

Figure 2. Palmyra Museum, March 2016. Copyright Mikhail Voskresenskiy/Sputnik.

with privileged access to the World Heritage Fund. ${ }^{33}$ Although these public endings may be the first to come to mind upon hearing the phrase 'how collections end', we have sought to go beyond such well-known cases. Here, we wish rather to characterize the various and subtle endings that are regular or even essential aspects of maintaining collections over time.

Repatriation or restitution are very different forms of finality - and in fact some have argued that the concept of finality in these cases is inappropriate. ${ }^{34}$ The origins of this set of practices lie in supposed violations of the customs of war. 'Restitution after war is an old issue', writes legal historian Margaret Miles, 'mentioned at least as far back as the reign of Persian King Cyrus the Great in the mid 6th century BC'. 35 The earliest repatriations involved returning captives to their native lands, but the formal concept seems to have coalesced around the restoration of religious statuary that had been taken in battle. Ironically, the modern legal framework for repatriation was developed at precisely the same time as the Parthenon Marbles were being moved to Britain: Lord Elgin's June 1815 offer to sell the Marbles to the British Museum was held up by the Battle of

33 Claire Smith, 'The Islamic State's symbolic war: Da'esh's socially mediated terrorism as a threat to cultural heritage', Journal of Social Archaeology (2016) 16, pp. 164-188.

34 Neil G.W. Curtis, 'Repatriation from Scottish museums: learning from NAGPRA', Museum Anthropology (2010) 33, pp. 234-248, esp. 239.

35 Margaret M. Miles, 'Still in the aftermath of Waterloo: a brief history of decisions about restitution', in Peter G. Stone (ed.), Cultural Heritage, Ethics, and the Military, Woodbridge: The Boydell Press, 2011, pp. 29-42, 29. 
Waterloo, a conflict that resulted in the first systematic return of plundered treasures. ${ }^{36}$ The framework developed in the years after 1815 involved the concept of the 'natural' home of cultural products - a legal and moral principle set directly against the dominant cultural logic of acquisition and appropriation. ${ }^{37}$

Over the last quarter-century, nation states have demanded the return of objects of value removed by colonial or imperial powers. Here, a collection might 'end' for one group, but begin for another. Indeed, the change in status of the object calls into question the entire concept of 'ending', as the group to whom the object has been returned is likely to see the transaction quite differently. Indigenous people in North America and Oceania have received repatriated objects, which may be reincorporated into cultural practices, displayed in indigenous museums or, in the case of human remains, reburied (Kakaliouras, this issue; see also Figure 3). We see a quite different view of the relation between burial and the correct fate of remains in the case of the mass burial of body parts of victims of Nazi injustice that had been uncovered in German medical collections in the 1980s. This is an ending somewhere between repatriation and destruction, and is by no means an end to the issue. In these cases, debate continues over whether these remains should be left where they are, excavated and given a more auspicious burial, or retained in the hope that genetic analysis can identify them and repatriate them to surviving relatives. ${ }^{38}$ These varied examples illustrate that what is at stake in repatriation debates is the value and values we place on objects and on their relation to people who have rights and interests in them.

Such competing rights and interests can have ontological implications. Some objects have competing repatriation claims, or cannot be repatriated owing to missing documentation, or have been claimed by indigenous groups but remain in museums. These objects may appear to become split, not just between different kinds of collection, but between different ontologies: different states of being. As described by Ann Kakaliouras (this volume), a particularly famous set of skeletal remains excavated in the US has become known both as Kennewick Man and as the Ancient One. ${ }^{39}$ Sustained ambiguities between a collection and its end can also extend outside the walls of museums. Mirjum Brusius explains that non-Western modes of preservation might include recycling, cohabitation and reconstruction ${ }^{40}$ - as they did for communities of people living among the ruins of Palmyra. ${ }^{41}$ What looks like an 'end' - in this case, a 'heritage' landscape shared with the paraphernalia of human lives - could be another form of conservation. The corollary of this is also true: what looks like preservation could be a path to

36 Miles, op. cit. (35).

37 Margaret M. Miles, 'War and passion: who keeps the art?', Case Western Reserve Journal of International Law (2017) 49, pp. 5-21.

38 Paul Weindling, "Cleansing” anatomical collections: the politics of removing specimens from German anatomical and medical collections 1988-92,' Annals of Anatomy (2012) 194, pp. 237-242.

39 Ann Kakaliouras, 'An anthropology of repatriation', Current Anthropology (2012) 53, pp. S210-S221.

40 Mirjam Brusius, 'Towards a history of preservation practices: archaeology, heritage, and the history of science', International Journal of Middle Eastern Studies (2015) 47, pp. 574-579.

41 Wendy M.K. Shaw, 'Preserving preservation: maintaining meaning in museum storage', in Brusius and Singh, op. cit. (20), pp. 153-168. 


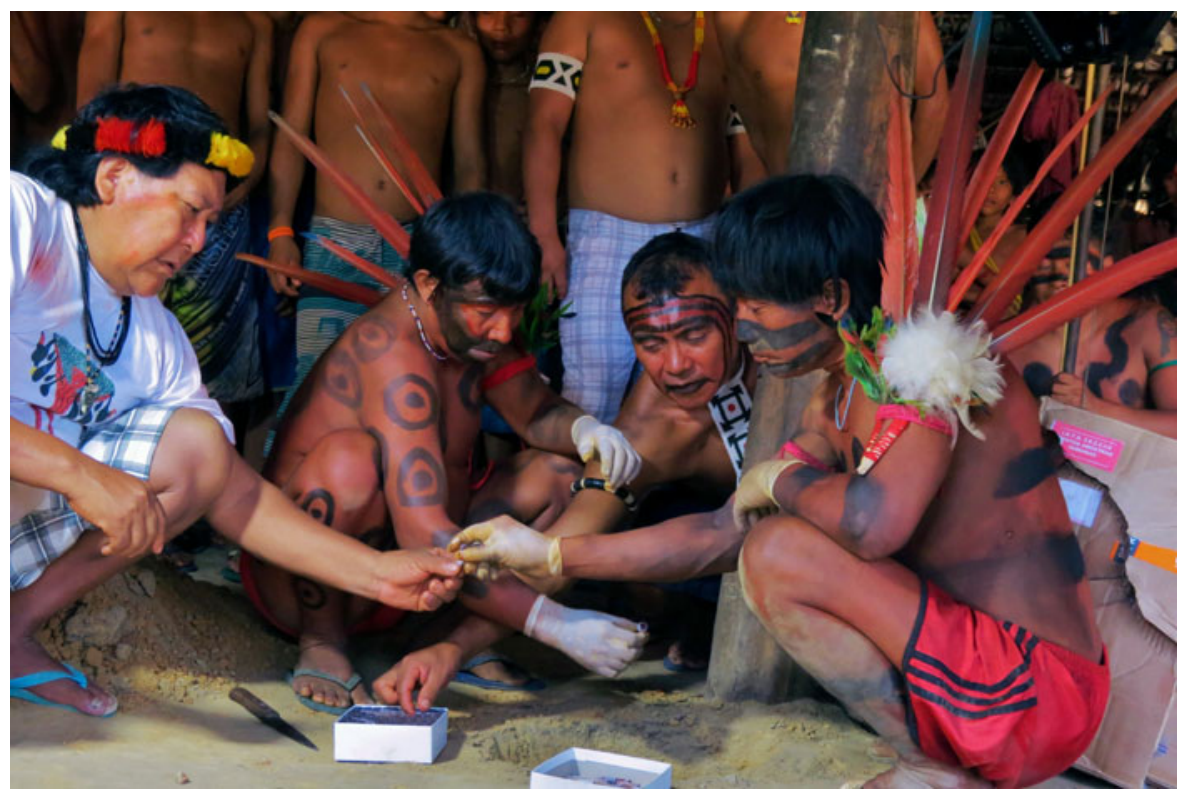

Figure 3. Davi Kopenawa and other Yanomami burying recently returned blood samples in a funerary ceremony, April 2015. Copyright Estêvão Benfica - Instituto Socioambiental.

destruction. This was the case at another site in Syria, where the Islamic State destroyed the ancient city of Nimrud because it had been excavated and preserved in the name of international heritage. Other sites that had been overlooked by the Western heritage gaze escaped harm.

These many and varied ways of ending draw attention to why things are collected in the first place: because they have value for those who collect and maintain them, and perhaps for those who are denied access to them. Their 'end' in this sense refers to their purpose in addition to their conclusion. Such purposes might range from sovereign nation or empire building to personal status, aesthetic pleasure, cultural development, religious worship, tools for producing knowledge and anything in between. Below a certain threshold of perceived value, collections might be in danger of dispersal. Collections that are seen as out of date, irrelevant, or a waste of space may be saved from their end if they are 'caught' by another net that incorporates new purposes and new forms of value. The combination of purposes that affix to a particular collection are interwoven into a net of significance that keeps collections together by eliciting acts of care. ${ }^{42}$ Ending may happen when this net of significance and care unravels, or when another net of significance and care (such as indigenous ownership) reassembles the collection in a new way.

42 Maria Puig de la Bellacasa, 'Matters of care in technoscience: assembling neglected things', Social Studies of Science (2011) 41, pp. 85-106. 


\section{'Working' and 'unique' collections}

Endings are heterogeneous, complex and even productive. But how have they been conceived over time? How might we as historians talk productively about processes that often appear accidental or too far from human intention to have left a mark on the historical record? One way forward is to historicize the concept of ending within different kinds of collections. In 1895 the museum administrator George Brown Goode made the capitalized exclamation that 'A FINISHED MUSEUM IS A DEAD MUSEUM AND A DEAD MUSEUM IS A USELESS MUSEUM' ${ }^{43}$ For Goode, museums must always be in flux, always re-evaluating and remaking their collections. Put another way, collections must 'remain relevant' as they travel through time or risk endangerment, even if the objects they assemble are materially secure. Hence, counterintuitively, the persistence of a collection might require the destruction (or loss, or using up) of its objects: countless natural-history specimens have been consumed and replaced in the pursuit of the very teaching and research activities that necessitate natural-history museums.

This recalls an important distinction, also made towards the end of the nineteenth century, by the Cambridge museum administrator, antiquarian and bibliophile John Willis Clark. He argued that an institution that houses collections could 'be considered from two very different points of view': as 'a workshop, or as a Museum' ${ }^{44}$ Clark was specifically talking about the two alternatives facing library collections. In the 'workshop' model, books would be merely sources of information. In this sense, the library would become 'a gigantic mincing-machine, into which the labours of the past are flung, to be turned out again in a slightly altered form as the literature of the present'. ${ }^{45}$ The library-as-'Museum', conversely, would be 'a temple or haunt of the Muses ... such a place is as useful as the other - every facility for study is given - but what I may call the personal element as affecting the treasures there assembled is brought prominently forward' ${ }^{46}$ In drawing this distinction, and advocating the cultivation of libraries that shared the function of workshop and museum, Clark was inaugurating the study of provenance through material traces - for him, the museum not only was a 'haunt of the Muses' but was itself haunted by the personalities of objects. ${ }^{47}$

Clark's point can be usefully generalized to help make sense of the many and varied endings considered in this collection of essays. If the collection is a 'workshop', then it consists not of unique objects but of useful ones: one analogy would be a library, where one copy of a book can (usually) be substituted for any other. Objects in what we will call 'working' collections are valued for their usefulness to a particular

43 Quoted in Steven Lubar, Lukas Rieppel, Ann Daly and Kathrinne Duffy, 'Lost museums', Museum History Journal (2017) 10, pp. 1-14, 1.

44 John Willis Clark, Libraries in the Medieval and Renaissance Periods, Cambridge: Macmillan and Bowes, 1894, p. 5.

45 Clark, op. cit. (44), p. 6.

46 Clark, op. cit. (44), p. 6.

47 Our approach to the end of collections is itself haunted by work on the vibrancy of matter and objects; see Jane Bennett, Vibrant Matter: A Political Ecology of Things, Durham, NC and London: Duke University Press, 2010; and Karen Barad, Meeting the Universe Halfway: Quantum Physics and the Entanglement of Matter and Meaning, Durham, NC and London: Duke University Press, 2007. 
community that is often a single discipline: think of geneticists' flies, craniometrists' skulls or epidemiologists' data sets. Changes in scientific disciplines might trigger obsolescence (for blood cards collected in East Timor, see Roque, this issue), as might bureaucratic or ethical barriers to access (such as skeletal material in the US; see Kakaliouras, this issue). To resist such ends, the working collection must remain relevant to the communities it serves, which may mean a vigilant commitment to de-accessioning objects (Bangham, this issue).

If the collection is considered, in Clark's sense, as a 'Museum', then each object is unique and cannot be substituted - objects are haunted by their provenance. In this case, books would be examined as objects with a distinctive history - a particular scholar's copy of a text, annotated, bound in a certain way and so on. Objects considered in this way are, in a strong sense, relics: remnants from an earlier time that are venerated for their authenticity. They are recognized for, and framed by, their unique historical value. Here, however, the terminology gets tricky: some institutions called museums, such as natural-history museums, may function more like a 'workshop' according to Clark's definitions. For clarity, then, instead of Clark's 'Museum' terminology we will use the term 'unique collections'.

As Clark himself recognized, many collections have both 'working' and 'unique' characteristics. And some collections or objects shift from one category to the other. Much of the historical interest in the case studies in this issue occurs precisely at points of confusion or movement between the two poles of the working and the unique collection. The two collections that John Willis Clark was most closely involved with are also illustrative here. He was an avid supporter of and contributor to the collections of Cambridge's University Library, and just prior to his lecture the library had formed its pioneering 'Adversaria' collection. ${ }^{48}$ This consisted of books that contained traces of past ownership, allowing scholars to study the reception of works in direct relation to the materiality of their production - what Clark called 'the personal element':

The development of printing, as the result of individual effort; the art of bookbinding, as practised by different persons in different countries; the history of the books themselves, the libraries in which they have found a home, the hands that have turned their pages, are there taken note of. Modern literature is fully represented, but the men of past days are not thrust out of sight; their footsteps seem to linger in the rooms where once they walked - their shades seem to protect the books they once handled. ${ }^{49}$

In this way, Clark and his colleagues in the University Library were at the very beginning of what has now become one of the most prominent branches of research into the specificities of the material objects of knowledge - namely studies of the material text. ${ }^{50}$

48 See Henry Richards Luard, A Catalogue of Adversaria and Printed Books Containing Ms. Notes Preserved in the Library of the University of Cambridge, Cambridge: Cambridge University Press, 1864; also Charles Sayle's provenance index, begun in 1894, Cambridge University Library Manuscript Collection, MS Add. 6450.

49 Clark, op. cit. (44), pp. 6-7.

50 A manifesto for the study of textual particularity can be found in D.F. McKenzie, Bibliography and the Sociology of Texts, Cambridge: Cambridge University Press, 2004. 'Material text' is one amongst many 
This discipline is premised on the importance of uniqueness in the production of seemingly identical objects, and is a bastion against the dispersal of collections. In this way, Clark's distinction has been an important one for the development of the humanities, even in their most recent guises: the emphasis on materiality, provenance and reflexivity in the history of knowledge is to be found in embryo in the notion of a unique collection in Clark's sense.

If we turn, however, to the museum that Clark himself oversaw - the Cambridge Museum of Zoology and Comparative Anatomy - we find a collection caught between the 'working' and 'unique' categories (Figure 4). Clark inherited the stewardship of the Comparative Anatomy collection from his father, William Clark, and from 1865 he laboured to incorporate the anatomical material with zoological collections acquired from the Cambridge Philosophical Society. In synthesizing a 'working' museum, fit for students, researchers and the public, Clark never completely effaced the historicity of either the zoological or the comparative-anatomy collections, and the unified Museum of Zoology was only brought into being after his death. This meant that the preservation of the separate provenances of the two collections - their uniqueness worked against the integration of the museum into the new 'biological' paradigm that was sweeping European museums in the late nineteenth century. Synthetic elements like new evolutionary displays added in the early twentieth century, had to be introduced in order to keep the collection relevant to teaching; that is, to keep it 'working'.

Blood samples collected from thousands of Indigenous Australians from the 1950s to the 1980s and stored at the Australian National University in Canberra provide a twentieth-century example of a collection with a shifting and overlapping designation. These samples were assembled by British-born geneticist Robert Louis Kirk for the purposes of understanding human biological diversity in Aboriginal people, a population of intense interest to scientists due to their long isolation from other population groups. For four decades, the blood samples were analysed for novel proteins and circulated through Kirk's wide network of collaborators. In the 1980s, Kirk and his colleagues noted the rise of the indigenous repatriation movement and wondered if and how the blood samples in their freezers might be implicated. ${ }^{51}$ At the time, written informed consent was emerging as the gold standard of research ethics. The absence of evidence of consent for Kirk's samples, which had been collected with verbal consent from people who generally had a poor grasp of English, began to be seen as a risk. In 1982, when Kirk arranged for placental samples from Aboriginal mothers to be salvaged by midwives and sent to the United States for geneticist Allan Wilson's groundbreaking study of global mitochondrial DNA diversity (the 'mitochondrial Eve' study), Kirk appeared to be aware that this mode of collecting was no longer considered acceptable. He asked Wilson to exclude his name from the article's acknowledgements. Due to an

contenders for the object of study; see Boris Jardine, 'Paper tools: the state of the discipline', Studies in History and Philosophy of Science A (2017) 64, pp. 53-63.

51 Emma Kowal and Joanna Radin, 'Indigenous biospecimen collections and the cryopolitics of frozen life', Journal of Sociology (2015) 51, pp. 63-80, 63. 


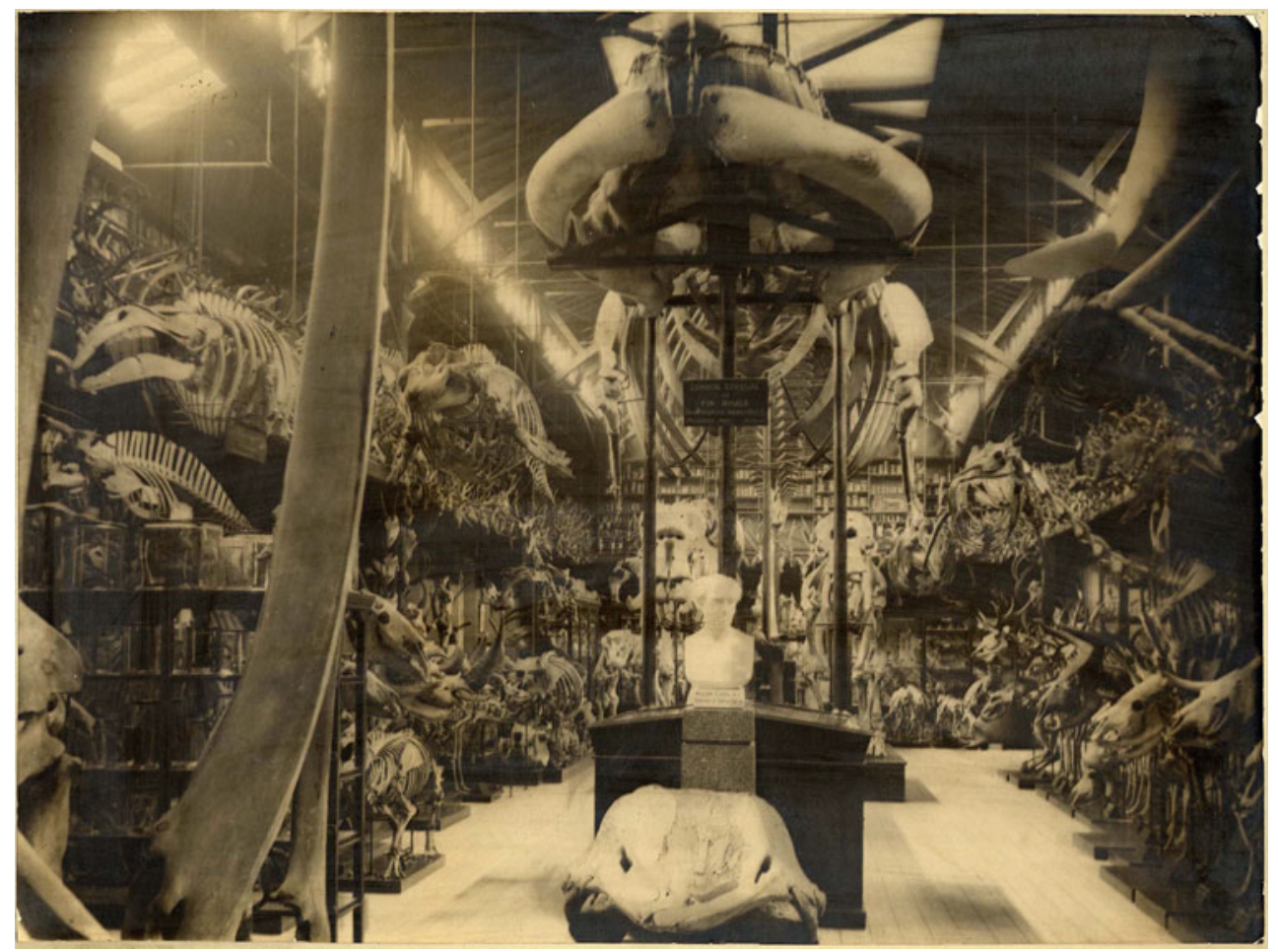

Figure 4. The Comparative Anatomy section of the Museum of Comparative Anatomy and Zoology, University of Cambridge, c.1900. This was the final form of the main part of the museum under Clark's stewardship. The bust is of William Clark, who acquired many of the specimens in his role as professor of anatomy - so the unique provenance of the collection (its 'personal' element) was preserved, even as the collection expanded. Eventually the various subcollections (Comparative Anatomy, Zoology, Ornithology) in the museum were integrated. The bust of Clark still stands in the lobby of the Department of Zoology, though it is no longer associated with the museum. Copyright Museum of Zoology, University of Cambridge.

'increase in the difficulty of getting samples from localities in this country', he preferred his contribution to Wilson's collection to remain anonymous. ${ }^{52}$

Episodes such as this signalled an ontological shift (explored above in relation to bones) whereby the samples gradually ceased to be tools for scientific enquiry and began to be extensions of the Indigenous polity, and therefore rightly under the control of Indigenous people. ${ }^{53}$ Concerns about the ethics of using the blood samples, initially tentative, escalated until a voluntary moratorium on their scientific use was imposed by the director of the John Curtin School for Medical Research (the institute housing the collection)

52 Letter from Bob Kirk to Allan Wilson (UC Berkeley), 16 April 1982, ANU Human Genome Archive. See Rebecca L. Cann, Mark Stoneking and Allan C. Wilson, 'Mitochondrial DNA and human evolution', Nature (1987) 325, pp. 31-36.

53 Emma Kowal, 'The vulnerable object of Indigenous research ethics', Australian Journal of Anthropology (2014) 25, pp. 390-392; Kowal and Radin, op. cit. (51). 
in the late 1990s. At this point, the samples had completed their transformation from a working collection available to science to a unique collection of biological substance, attached to its donors and potentially repatriable. This transformation became a reality for another blood sample collection similar to Kirk's. Blood collected from the Yanomami people of Brazil by Napoleon Chagnon and colleagues was stored at the National Institutes of Health (NIH) in Bethesda, Maryland. Following an ethics scandal that broke in the 1990s, the Yanomami and their advocates requested that these samples held by NIH be returned, a request that was eventually fulfilled in 2015 (Figure 3). ${ }^{54}$

So far, repatriation of Kirk's samples has not been requested. Instead, the samples have been drawn into contemporary ethical frameworks through identifying their donors, or, in cases where the donor has passed away, a close relative, and obtaining written informed consent to study the sample. If samples cannot be traced to a living person who can provide or withhold consent, they are effectively 'orphaned', divorced from networks of care and therefore unable to be used. ${ }^{55}$ Thus a working collection of 'Indigenous' DNA samples must simultaneously be a unique collection in order to maintain both scientific and ethical viability.

The essays in this issue follow the cues of the case studies we have introduced here, elaborating and extending the always incomplete distinction between a 'working' collection and a 'unique' collection from the point of view of endings. One major contribution of the essays is to bring a common analytic framework to bear on collections in laboratories, digital databases, private storage and museums. Historical writing on these spaces has tended to emphasize differentiation; scientists' working collections, in particular, have rarely come under consideration as collections. ${ }^{56}$ Nevertheless, collections and collecting have remained central to the production of scientific knowledge. ${ }^{57}$ Just like museums, biomedical collections of specimens, stocks or data also require curators. ${ }^{58}$ Bangham's paper (this issue) explores the ongoing appraisal, evaluation and de-accessioning carried out by the curators of living biological stock centres to maintain the value and meaning of collections used for genetic research. Curation has also become crucial to sequence-intensive biology: over the last twenty years, the 'biocurator' - responsible for selecting, editing and managing information in biological databases - has become a critical part of the biological and biomedical science infrastructure. ${ }^{59}$ Skinner and Wienroth's paper (this issue)

54 See Patrick Tierney, Darkness in El Dorado: How Scientists and Journalists Devastated the Amazon, New York: W.W. Norton \& Company, 2000.

55 Emma Kowal, 'Orphan DNA: indigenous samples, ethical biovalue and postcolonial science', Social Studies of Science (2013) 43, pp. 578-598.

56 But see Joanna Radin and Emma Kowal, 'Indigenous blood and ethical regimes in the United States and Australia since the 1960s', American Ethnologist (2015) 42, pp. 749-765.

57 Bruno J. Strasser, 'The experimenter's museum: GenBank, natural history, and the moral economies of biomedicine', Isis (2011) 102, pp. 60-96; and Strasser, 'Collecting nature: practices, styles, and narratives', Osiris (2012) 27, pp. 303-340.

58 Sabina Leonelli, Data-Centric Biology: A Philosophical Study, Chicago and London: The University of Chicago Press, 2016; Hallam Stevens, Life out of Sequence: A Data-Driven History of Bioinformatics, Chicago and London: The University of Chicago Press, 2013.

59 Sabina Leonelli and Rachel A. Ankeny, 'Re-thinking organisms: the impact of databases on model organism biology', Studies in History and Philosophy of Biological and Biomedical Sciences (2012) 43, pp. 29-36. 
describes the twenty-year history of the UK's forensic National DNA Database and the curatorial erasures required to respond to changing political, judicial and ethical frameworks. That example strikingly demonstrates how de-accessioning, destruction and deletion can be crucial for the continued legitimacy of a collection.

Moreover, objects can move between the museum and lab. Forgotten museum collections might find a second life as sources of scientific knowledge (like the plasmodia in old blood samples); obsolete laboratory collections can be re-collected as objects with a historical identity. When the organizing logic of the collection of working objects in a laboratory breaks down, it becomes possible for those objects to be disposed of, perhaps first into a cupboard within the laboratory, or perhaps then as a display of historical apparatus in a foyer or corridor. ${ }^{60}$ Once this first afterlife is extinguished, laboratory equipment sometimes finds its way into a museum: a repository of doubly obsolete items. The apparatus and staff of the museum now step in to revivify the object outside the laboratory as a unique relic of the past (Jardine, this issue). Ad Maas has discussed the problems this poses for museum curators, and his solution - to critique the 'relic' model of scientific collecting, in favour of a context-sensitive 'organic' approach closely maps onto our 'unique' and 'working' model. ${ }^{61}$

Three of the papers in this collection - by Roque, Hopwood and Jardine - explore the fates of laboratory objects. As sociologist Kevin Hetherington observes, disposal whether into landfill or the museum - is never a complete process: objects leave traces, and absence plays a social role after the object has been disposed. ${ }^{62}$ Ricardo Roque (this issue) traces the formation and persistence of thousands of blood group paper cards originally collected in the 1940s-1960s by the Portuguese Overseas Science Board from then colonies in Africa and Asia. Roque unpacks the rich material-semiotic assemblage condensed in the cards: a classificatory tool, an instrument of scientific colonialism and anti-serum mixed with indigenous blood. The cards proved to be remarkably durable, surviving multiple institutional deaths in the (ultimately false) hope that their value could be translated into the currency of genomics. Finally abandoned by their remaining scientific custodian, the cards ended up as unique items in an anthropological museum. Roque draws on Bahktin's notion of a 'chronotope' to understand how the cards were infused with the space and time of their formation, a colonial legacy that continues to act on and through the cards long after formal imperial structures have ended.

Laboratory equipment that has ended up in the museum can also leave such traces: a thing discarded by science but salvaged by history. Boris Jardine's essay explores the role of Cambridge laboratories, museums, historians and curators in the development of the science museum as a discrete space for scientific memory. In the spirit of this collection, Jardine's focus is not on the beginning of science museums per se, but on a particular

60 We are drawing here on the notion of first and second burial as described in Kevin Hetherington's influential analysis of disposal, 'Secondhandedness: consumption, disposal, and absent presence', Environment and Planning D (2004) 22, pp. 157-173.

61 Ad Maas, 'How to put a black box in a showcase: history of science museums and recent heritage', Studies in History and Philosophy of Science A (2013) 44, pp. 660-668.

62 Hetherington, op. cit. (60). 
kind of collecting that is institutionally fragile and therefore susceptible to multiple beginnings and ends. Taking the 1936 Historic Scientific Apparatus exhibition and the book that followed in its wake, Early Science at Cambridge, as his point of departure, Jardine explores the changing shape of the 'museum in the lab' in the late nineteenth and early twentieth centuries. Collections of objects helped laboratories define and market themselves at a time when museums were highly respected modern institutions but laboratories struggled to articulate their purpose and function. Laboratories collected 'historical' objects to memorialize their treasured scientists, particularly those who met untimely ends, to celebrate the commercially successful scientific instruments they produced, or to cannibalize objects for new purposes (such as instruments for students). Jardine suggests that the emergence of science museums and the associated end of many 'museums in the lab' demonstrates how the new epistemological success of laboratories meant they no longer needed their 'scientific past'.

These complex issues of time and memory are also prominent in Nick Hopwood's contribution. Hopwood shows the ways in which collections came to play a central role in intergenerational negotiations through the middle of the twentieth century. The case of the anatomist Ferdinand Graf Spee's personal and teaching collections nicely illustrates the multiplicity of endings we have emphasized here: teaching collections needed to be updated and were no one individual's property, personal research collections were not necessarily as valuable as published images or descriptions, and the changing fortunes of institutions through periods of political turmoil placed a strain on the maintenance of collections. The fate of Spee's collection was sealed only when his institute was destroyed during the Second World War.

These essays illustrate how the museum and the lab are entangled by the process of acquisition, as are personal and institutional collections in the process of memorialization. The complex ways in which collections come to stand for the legacy of individuals is also at issue. Collections sometimes carry the names and memories of those who initiate them, so by looking at endings we see the representation of the collector at a point of radical instability. For Jardine, the physicist James Clerk Maxwell could only be celebrated once his own style of collecting was eradicated. In Hopwood's study of a memoir, the view of Spee is always filtered through the generic conventions of Benninghoff's elegiac prose. As the case studies here illustrate, the final significance of collectors and the meanings of objects are rarely settled. This point can be generalized: a working collection can always be unsettled if the historical or cultural uniqueness of its objects is recognized.

\section{Multiple histories}

Endings are not really endings. Seen from another angle, the 'end' of an object or collection is merely a shift in the dominant account of its cultural value. ${ }^{63}$ When an object is accessioned into a museum collection, its 'historical' value reflects a decision to tell a

63 Arjun Appadurai, The Social Life of Things, Cambridge, New York and Victoria: Cambridge University Press, 1986. 
specific historical narrative, which itself is a product of particular histories and power relations. The custody and display of the Parthenon Marbles at the British Museum attaches them to a history of the European Enlightenment. ${ }^{64}$ In another example, Jardine (this issue) describes how - between the 1870s and the 1970s - a sixteenthcentury Florentine thermometer moved between collections, and shifted in its significance, from being a demonstration piece in the history of measurement, to a forgotten curio, to a celebrated example of an early thermometer. This last move involved the privileging of one provenance (via the Accademia del Cimento) at the expense of another (via the physicist James Clerk Maxwell). This illustrates the defining skill of modern curation: the ability to select from the many narratives that each object is capable of telling. If not tightly controlled (and sometimes even if it is), multiple historicity can lead to administrative peril. Any given object might move between collections, religious institutions, communities or university department corridors without much disruption; yet each stakeholder has the potential to threaten the interests of others and, with them, the integrity of collections.

This points to an important - even surprising - feature of objects in unique collections: they often have a wider range of stakeholders than objects in a working collection. The notion of 'unique' and 'historical' value suggests a consensus among a group with the power to create institutions of preservation, whether it be a small historical society, a religious or cultural institution or a national museum. But having more people interested in an object - a wider net of significance, one might say - may have important consequences, especially concerning endings. Objects in such collections are likely to be retained and preserved, materially surviving instead of surrendering to decay and loss. But the very persistence of a collected object, especially within a unique collection, means it may be subject to a wide range of competing claims which can jeopardize its continued presence in that collection.

Repatriation happens when one group is granted the rights to remove an object altogether from a museum collection, thus repositioning or remediating the history embedded in the object in its museum context. At the level of the individual object, collection or institution this presents an apparent challenge to curatorial order, although in many cases this challenge has been embraced. Legal frameworks and historical circumstances differ drastically from country to country, and these differences are manifest in the way collections are discussed, in the ways that images of objects are and are not used, and in the expected roles of historians of collections in debates over contested objects.

A paper presented at the 2017 Cambridge workshop illustrated how assumptions about what constitutes an object or collections vary by locality and political context, and cannot be taken as self-evident. Andrea Witcomb and Alistair Paterson focused on five photographs of a personal collection of Aboriginal artefacts from Western Australia formed in the $1920 \mathrm{~s} .{ }^{65}$ Witcomb had recently discovered the photographs in

64 Neil G.W. Curtis, 'Universal museums, museum objects and repatriation: the tangled stories of things', Museum Management and Curatorship (2006) 21, pp. 117-127.

65 Andrea Witcomb and Alistair Paterson, 'Collections without end: the ghostly presence of Captain Matthew McVicker-Smyth's Western Australian Collection', paper presented at the How Collections End workshop, Cambridge, 24-26 October 2017. 
a public archive. They contain images of artefacts known to be sacred to Aboriginal people (the artefacts themselves are presumed to be lost or dispersed). In preparing their paper, Witcomb and Paterson discussed with their colleagues whether they could show the photograph at the workshop. They decided not to show the images, as it is considered inappropriate in Australia to show images of sacred objects without the express permission of the relevant traditional owners. Many of the European attendees at the workshop found it surprising that a photograph of objects was treated somewhat like the objects themselves would be (if they were found still to exist). They were equally surprised that the lost collection was not considered to have ended: in a display of sympathetic magic, images of the collection required the same care as would the objects themselves. By contrast, the Australian participants, familiar with the post-colonial context of Australian collections, were unsurprised that the images could not be shown and that resources were being devoted to locating living Aboriginal people who could make decisions about who could access the images and under what circumstances.

An encounter directly after the Cambridge workshop drew a particularly stark contrast with the power relations that dictate Australian endings. An author of this introduction (Kowal) and another workshop participant (Anne Faithfull) were invited to visit the University of Cambridge Duckworth Collection. This contains the remains of 18,000 people collected from around the world and represents over two hundred years of anatomical and anthropological collecting of human remains of all kinds, 'from blood samples to hair bundles, single bones, complete skeletons, mummies and decorated skulls' ${ }^{66}$ Many of its specimens were collected in the context of colonial domination and are of likely interest to indigenous people and historians as unique objects and relics of imperialism. Some may well become subject to repatriation claims by their source communities in the future. So far, however, the Duckworth has succeeded in presenting itself as a working collection of biological anthropology specimens rather than as a collection of 'unique' museum objects. Its website explains that the collection 'continues to play a central role in each new phase of research into the biology and behaviour of humans'. It is likely that if it were to be recognized as a unique collection, it would be more susceptible to a wider web of claims on its objects, including claims for repatriation. In what was admittedly a private tour of the collection, the visitors were shown shelves full of skulls originating from around the world, many of them in plasticfronted boxes to facilitate visual inspection. ${ }^{67}$ While the lost Western Australian collection is not allowed to end, and continues a new life in photographic form, the Duckworth resists the global political forces that might see the end of its control over its collections. In this issue, Ann Kakaliouras explores the relationship between repatriation and the fates of disciplines, methodologies and narratives about human origins. Tracing the twenty-year history of Kennewick Man/the Ancient One, Kakaliouras ties the skeleton's

66 See www.human-evol.cam.ac.uk/duckworth-lab.html, accessed 25 April 2019.

67 One exception to this was a small section of one shelf containing boxes of Hawaiian skulls that was covered with a black cloth. It was explained to us that Hawaiian representatives had visited the collection and agreed that the remains should stay there for research purposes but requested that they be covered when not in use, a request that they were happy to comply with. The black cloth functions as a kind of shrine to alternative claims on the collection, or a talisman that wards off much wider claims. 
repatriation and burial to the demise of an anthropological category (the 'Palaeoamerican') and to the decline of the discipline of craniometry.

More, even, than the end of a collection, repatriation can (for some) represent the end of collecting, at least as a supposedly politically neutral or unproblematically 'scientific' activity. ${ }^{68}$ As the example of Kirk's placental samples outlined above illustrates, collecting may be perceived as 'under threat' when the power relations surrounding the practice come under increased scrutiny, not only, but especially, for collections that have colonial histories. A shift in the gaze of curators, and of many consumers, has led to greater attention being given to the power relations embedded in the provenance of objects (as opposed to their aesthetics or singular historical meaning). ${ }^{69} \mathrm{~A}$ more radical view is that objects do not bear multiple histories simultaneously at all, because each different understanding of an object places that object in a different world, and translation between these worlds is near impossible. ${ }^{70}$ If an object is repatriated its ontological status is changed, often overriding conventional curatorial notions of provenance. ${ }^{71}$ Rather than adopt a non-committal view of the inherent interest of multiple provenances or a radical view of multiple ontologies, we follow our authors in examining the power relations at play both in making claims over objects and in making claims over historicity or ontology. Again, collections are only secondarily assemblages of objects: they are primarily assemblages of interests and power relations.

At the same time as collecting might be ending, however, new technologies are multiplying collection possibilities. ${ }^{72}$ Imaging and 3D printing, for example, can massively proliferate the scope of what is collected and displayed, reconfiguring relations between curators, objects and consumers. Curator Elizabeth Neely and museums scholar Miriam Langer argue that encouraging the public to manipulate and produce their own artefacts from scanned museum objects 'both increase[s] dwell time with the object or its digital surrogate and deepen[s] visitors' emotional relationship with the object by allowing them to make it their own' ${ }^{73}$

68 Dorothy Lippert, 'Not the end, not the middle, but the beginning: repatriation as a transformative mechanism for archaeologists and indigenous peoples', in Chip Colwell-Chanthaphonh and T.J. Ferguson (eds.), Collaboration in Archaeological Practice: Engaging Descendant Communities, Lanham, MD: AltaMira Press, 2008, pp. 119-130.

69 Among many other ethical issues related to the museum sector see the Museum Management and Curatorship special issue New Directions in Museum Ethics (ed. Janet Marstine, Alexander A. Bauer and Chelsea Haines) (2011) 26; Janet Marstine (ed.), The Routledge Companion to Museum Ethics: Redefining Ethics for the Twenty-First-Century Museum, London and New York: Routledge, 2011; Rodney Harrison, Sarah Byrne and Anne Clarke (eds.), Reassembling the Collection: Ethnographic Museums and Indigenous Agency, Santa Fe: SAR Press, 2013. Also relevant is the work of the Institute of Museum Ethics, founded in 2007; see 'Mission and history', at museumethics.org/about, accessed 25 April 2019.

70 See Marisol de la Cadena, 'Indigenous cosmopolitics in the Andes: conceptual reflections beyond “politics”, Cultural Anthropology (2010) 25, pp. 334-370.

71 Kakaliouras, op. cit. (39).

72 See, for example, the National Science Foundation White Paper, issued while this introduction was in press, which argues that 'the United States should create an all-encompassing database of the billion stuffed, dried, and otherwise preserved plants, animals, and fossils in museums and other collections'. See the summary by Elizabeth Pennisi, 'Report urges massive digitization of biospecimens', Science (2019) 364, p. 115.

73 Liz Neely and Miriam Langer, 'Please feel the museum: the emergence of 3D printing and scanning', presented at the Museums and the Web 2013 conference, 17-20 April 2013, at mw2013. 
According to the argument of this introductory essay thus far, increasing the quality and quantity of regard (or attachment, or care) shown by a human towards an object - in this case, a human member of the public and a digitally mediated museum object - will extend the net of significance, and this may help preserve the object and its collection. ${ }^{74}$ But this raises a further danger hinted at by Neely and Langer, who comment, 'Open questions remain about the future of regulation surrounding the capture, ownership, copyright, sharing, and commercializing of "things" (i.e., models, derivatives, replicas)'. When collections are open-ended, endlessly proliferating, they take on a life of their own, and any ability to control their means and ends is threatened.

Similarly, images, casts and copies that have been made from a collection have complicated the multiple histories of objects and collections. Recent examples of what we might call 'referent' collections have included digital archives, such as the large collection of material relating to the history of genetics at the Wellcome Library, and detailed images of bones, such as the Ford Collection of Crania at the University of Michigan Museum for Anthropological Archaeology. ${ }^{75}$ Image, digital and cast collections produce new meanings and uses for collections, at new times and in new places. 'Every cast tells two stories. One ancient, one modern', declares the website for the Cast Collection at the Museum of Classical Archaeology at the University of Cambridge. ${ }^{76}$ In the case of the Wellcome Library and the University of Michigan, referent collections have vastly expanded conditions of access and circulation to the original material, with far more extensive users and audiences. Although, on the one hand, the creation of such collections helps to mitigate against loss, potentially making collections less vulnerable, in other instances, the creation and circulation of referent collections can result in a loss of access because 'originals' are no longer considered needed, or because the act of copying or image making can bring into view sensitivities around material that were previously not seen. When the Wellcome Library digitized its human genetics archives, starting in $2010,{ }^{77}$ those archives were reassessed for their content of 'sensitive personal data', in accordance with the Wellcome Library's Access Policy. During that labour-intensive process, a large number of papers were closed under the 2004 Data Protection Act, leaving some of the original documents inaccessible to historians for several more decades. In this case, the openness of the digital referent collection resulted in the partial closure of the original collection.

In other cases, the ability to control the circulation of objects and their referents (see Kowal, this issue) is out of reach once copies start proliferating. Thus Indigenous

museumsandtheweb.com/paper/please-feel-the-museum-the-emergence-of-3d-printing-and-scanning, accessed 25 April 2019. The formulation of 'dwell time' in this quote recalls Ingold's analysis of human interactions with the environment (including objects); see Tim Ingold, The Perception of the Environment: Essays in Livelihood, Dwelling and Skill, London and New York: Routledge, 2006.

74 While recognizing that being 'of interest' can, in some cases, put objects at increased risk of destruction, as illustrated by the case of Nimrud discussed above.

75 Wellcome Library digital collection Codebreakers: Makers of Modern Genetics, at wellcomelibrary.org/ collections/digital-collections/makers-of-modern-genetics; University of Michigan, Museum of Anthropological Archaeology, Ford Collection, at quod.lib.umich.edu/c/crania1ic (both accessed 25 April 2019).

76 See classics.cam.ac.uk/museum, accessed 25 April 2019.

77 Wellcome Library, op. cit. (75). 
repatriation experts in Australia have been concerned about CT (computerized tomography) images taken of human remains by holding institutions prior to returning skeletal material. High-resolution CT scanning has become a common tool for the study of human remains. With the advent of $3 \mathrm{D}$ printing, however, CT images can be readily used to print a replica of the scanned bones, and repatriation may therefore not be the 'end' that Indigenous communities expect it to be. In light of this, Indigenous people are beginning to request that all imaging data are also returned along with the physical objects. ${ }^{78}$ The problem of copies, replicas, models and images has been a preoccupation of scholars at least since Walter Benjamin noted in 1936 that the 'aura' of an object is diminished when technological reproduction 'substitutes for its unique incidence a multiplicity of incidences' ${ }^{79}$ In the case of electronic objects, such as scientific data or digital art, it can be difficult, if not impossible, to distinguish the 'original' artefact from its proliferations.

In some cases, copies can enhance the power of the original rather than diminish it. ${ }^{80}$ This was arguably the case for a famous photographic image of Sir Walter Baldwin Spencer, a prominent colonial collector of artefacts from Aboriginal Australians. A 1901 image of Spencer was re-created in physical form as a prop for an explicitly 'post-colonial' exhibition at the Melbourne Museum in the year 2000. In a deliberate reversal of the colonial gaze, a life-size model of the collector was ironically placed in a glass case. Emma Kowal's essay (this issue) focuses on the model's rich post-exhibition career as a problematic museum object. In another level of irony, the model itself was never officially part of the museum collection, but ended up informally collected by museum staff in an act grounded somewhere between nostalgia, superstition and rebellion.

One way in which objects and collections have resisted changes of identity is through the endurance of labels, indexes, lists, catalogues and databases (Porter, this issue). These bureaucratic technologies are vital components of collection infrastructures and have functions that go beyond their uses as finding aids. Writing - whether material or digital - is essential for maintaining the value of collections. Discussing histories of various genetic stock centres, Bangham (this issue) explores the technologies and labour needed to order, compare and circulate materials for biological research. As well as care, selection and managed destruction, a central feature of the curation work carried out by genetic stock centres is the management of information. Bangham describes how the closure of one biological stock centre was a consequence of being unable to 'keep up' with prevailing standards of documentation.

78 Repatriation manager, personal communication with Emma Kowal, December 2017. This relates to the broader topic of 'Indigenous data sovereignty' that is emerging as a critical issue in fields as diverse as indigenous studies, epidemiology and demography. See Tahu Kukutai and John Taylor (eds.), Indigenous Data Sovereignty: Toward an Agenda, Canberra: ANU Press, 2016.

79 Walter Benjamin, 'The work of art in the age of mechanical reproduction', in Benjamin, Illuminations (trans. Harry Zohn, ed. Hannah Arendt), New York: Schocken Books, 1969, pp. 217-251.

80 Michael Taussig, Mimesis and Alterity: A Particular History of the Senses, London and New York, Routledge, 1993. 
For museums, writing a number on an object, and entering corresponding information into the museum's catalogue, defines that object's accession. ${ }^{81}$ Those practices make associations between one object and another, and give that object historical value. In another paper presented at the Cambridge workshop, museum studies scholar Anne Faithfull traced the varied, and surprisingly flexible, museum classifications of two kinds of human biological material: hair and bones. Comparing the histories and fates of two samples of hair collected on the same day - accessioned respectively as 'hair' and 'cultural artefact' - Faithfull contrasted these with the classification and treatment of skeletal material ('human remains'). Museum classifications have powerfully determined the later fates of these materials: what they can say about human evolution and history, who qualifies as custodians, and how and where they can be displayed.

Collections can enter into a state of limbo if their documentation is lost or compromised. Prussian bombing during the 1871 siege of Paris prompted curators at the Muséum national d'histoire naturelle to rush the skull collection to the basement, separating specimens from their labels in the process. The fire did not reach that wing of the museum, but many items in the collection were irrevocably severed from their provenance, changing their identity. ${ }^{82}$ In the late nineteenth century, a collection of skulls from Macao and Timor arrived in a museum in Portugal without labels, leading to a heated debate about their authenticity. ${ }^{83}$ Today, a collection of 17,000 vials of frozen blood kept in freezers in the Department of Archaeology and Anthropology in Cambridge lies dormant because it has become detached from the documents that describe whom the samples are from. These samples now face an uncertain future as the paper records that accompany them are scoured for clues to the identity of the blood donors - a dramatic instance of a problem of data management common to all large collections. ${ }^{84}$

\section{Conclusion: from conflict and controversy to care and community}

If ending has not been a focus of traditional histories of collecting, the same cannot be said of the history of science. The dual meanings of end - purpose and finality - lie at the very origins of the discipline and mark significant points in its development. The first practising scientists to turn to history examined the ways in which their predecessors contributed to a process that had its culmination in the present; subsequent historians have paid more attention to radical disjuncture in the history of science. ${ }^{85}$ In recent

81 Curtis, op. cit. (64); Susan Stewart, On Longing: Narratives of the Miniature, the Gigantic, the Souvenir, the Collection, Durham, NC and London: Duke University Press, 1993.

82 Armand de Quatrefages to Ernest-Théodore Hamy, n.d. (after 8-9 January 1871), Muséum national d'histoire naturelle, Ms 2254, 'Correspondance des années 1860-1877', ff. 138r-139v. Thanks to Bronwen Douglas for this reference.

83 Ricardo Roque, 'Skulls without words: the order of collections from Macao and Timor, 1879-82', Journal of History of Science and Technology (2007) 1, pp. 113-154.

84 Jenny Bangham, 'Epilogue', in Bangham, Blood Relations: Transfusion and the Making of Human Genetics, Chicago and London: The University of Chicago Press, forthcoming.

85 An exemplar of the latter is Joseph Needham and Walter Pagel (eds.), Background to Modern Science: Ten Lectures at Cambridge Arranged by the History of Science Committee, 1936, New York and Cambridge: Macmillan and Cambridge University Press, 1938. 
historiography these two kinds of ending have become intertwined: historians of the experimental sciences have looked at completion and consensus; those looking at working communities have often examined the breakdown of scientific networks, through conflict, the loss of a common object of research, or the vicissitudes of history. ${ }^{86}$

Yet the canonical history of ending must still be Kuhn's The Structure of Scientific Revolutions, which explicitly contrasted the older, teleological historiography with a new 'image' of the history of science, involving the 'tradition-shattering ... rejection of one time-honored scientific theory in favor of another'. ${ }^{87}$ Because, for Kuhn, 'scientific fact and theory are not categorically separable', the arrival of new theories means that 'the scientist's world is qualitatively transformed' 88 - new facts are implied by new theories, while old facts cease to have meaning and are jettisoned from the store of scientific knowledge. Kuhn's language, especially in the introduction to Structure, is full of accumulative metaphors. The model he rejects is that of a 'stockpile' of ideas and practices, which exists as a kind of timeless 'collection'. ${ }^{89}$ The new history of science that Kuhn proposed was 'less than cumulative', ${ }^{90}$ and in this sense Structure can be thought of as an essay on the way in which collections of data, facts, laws, theories, methods and instruments end.

However, the sequence of paradigms identified by Kuhn, and even an interest in periodization per se, have not proved as useful to historians of science as the way in which Kuhn emphasized the work needed to sustain 'normal science' in the face of possible loss or change. In this issue, too, there is less focus on moments of revolutionary change, destruction or loss. Steering an analytical path that eschews both the cumulative advancement of science and abrupt shifts, we have examined the moments of loss and maintenance involved in even the most 'normal' of scientific processes - the care of stocks, the management of data, the transfer of objects from one location to another, the display (or not) of museum objects. The kinds of maintenance we describe are likely, we think, to be central to other areas of scientific work. If this is indeed the case, then a range of questions are raised across the sciences - about curatorial labour; about flows of credit and capital as they are fixed and represented in objects (including instruments, buildings, memorials and collections); and about the management, routine destruction and intellectual care of collections. Might we think of scientific work as more a matter of care and curation than experiment and discovery? Our contentions have been that even within such ordinary procedures of care and management, subtle but important changes can occur, that the threat of loss is a motivating factor in such acts of curation, and that routine destruction - 'pruning', as Bangham and her actors call it - is also central to the creative labour of maintenance.

Another way of putting this is that collections have temporalities quite different from the disciplines to which they relate. Like Kuhn did in his concept of the 'paradigm', we take this notion from art history. Krzysztof Pomian, for instance, has presented a robust

86 See, for example, Dániel Margócsy, ‘A long history of breakdowns: a historiographical review', Social Studies of Science (2017) 47, pp. 307-325.

87 Kuhn, op. cit. (8), p. 6.

88 Kuhn, op. cit. (8), p. 7.

89 Kuhn, op. cit. (8), p. 2.

90 Kuhn, op. cit. (8), p. 3. 
challenge to the art-historical model that emphasized a sequence of dominant tastes and patterns of patronage, emphasizing instead the highly idiosyncratic historiography of collections themselves. For Pomian, collections are 'anthropological events' which may not map onto modern disciplinary divisions, and which require their own political, social and economic analysis. ${ }^{91}$ Only by understanding collections in this way, he argues, will it be possible to account for the radical heterogeneity of private and public collections, the relationship between these two dominant kinds of collection, and ultimately the meaning of the 'universe' of collections which contains 'every natural object known to man, and every artefact, however strange'. ${ }^{92}$

This argument is easily imported into histories of the sciences, in just the same way that other aspects of the 'material turn' have challenged old orthodoxies, Kuhn's included. In this vein, Galison has argued that scientific instruments constitute a third 'layer' of scientific knowledge making, the other two being Kuhnian theory and observation. ${ }^{93}$ All three travel together but with differential timescales. Instrumental developments lead to new kinds of data and alter theories; observations with instruments are interpreted according to theoretical presuppositions; instrumental set-ups, especially on large scales, continue to determine research programmes just as other developments call those programmes into question. Scientific collections, in this schema, would constitute a fourth layer. Collections cannot be reduced to observation; they can be data but they are more than that, especially if new theoretical approaches cause scientists to go back to collections to reinterpret their constituent objects; collections have been called 'instruments', but they perform other functions too, sometimes involving non-scientific stakeholders.

What, then, of ending? Collections, in this account, complicate the Kuhnian notion of paradigm shift. Evidently, scientific collections can outlive theoretical changes in the disciplines they occupy. Entire disciplines disappear from the intellectual landscape, leaving only their collections behind (Roque, this issue). The contrary process, whereby difficulties encountered by collections themselves affect the parent discipline, are rarer, but may have dramatic consequences (Kakaliouras, this issue). Perhaps the most important way in which the question of ending bears on the history of science is that it shifts attention from the purely epistemological function of collections. As the papers in this issue make clear, when we foreground the materiality of collections - their vulnerability and their endurance - we attune ourselves to their role in power struggles over scientific authority, to the relationship between constituencies within different curatorial cultures, to the labour involved in preservation, and to the agency of collections, especially as this emerges in times of crisis. Collections - colligere - speak volumes about what it is we value, but it is when collections end that we most need to listen.

91 Krzysztof Pomian, Collectors and Curiosities: Paris and Venice, 1500-1800 (trans. Elizabeth WilesPortier), Cambridge: Polity Press, 1990, p. 4.

92 Pomian, op. cit. (91) p. 7. We do not, however, follow Pomian in seeing collections as existing outside economics - and in fact as many contributors show, it is precisely through questions of value that we can best grasp the patterns of accumulation and loss in the sciences.

93 Peter Galison, 'History, philosophy, and the central metaphor', Science in Context (1988) 2, pp. 197212, esp. $207 \mathrm{ff}$. 